\title{
TOXICOLOGICAL EFFECT OF THE DISINFECTANT BIOCID-30 ON CHICK EMBRYO
}

\author{
Ghada M. Gomaa, Yosef T.A. and Zahra A.A. \\ Pharmacology Department, Fac. of Vet. Med. Tanta Univ. (Kafr El-Sheikh)
}

\begin{abstract}
Two hundered and twenty chicken eggs were utilized in this experiment. The eggs were randomly divided into two main groups; the first dipped group includes 100 fertile eggs, which was subdivided into 5 subgroups, each of 20 fertile eggs.Two subgroups were dipped in Biocid-30diluted 1:300 for one and 5 minutes respectively.Another two subgroups were dipped in Biocid-30 diluted 1:400 for one and 5 minutes respectively. The last subgroup was used as control and dipped for 5 minutes in distilled water. The second main inoculated group contains 120 fertile eggs and subdivided into three subgroups. The first one (50 eggs) inoculated intra air sac by Biocid-30 diluted (1:300), while the second subgroup (50 eggs) treated in the same manner with Biocid-30 diluted 1:400. The last 20 eggs were inoculated with sterile saline solution and considered as a control group. Treatments were done at the first day of incubation, which carried out at $37 C^{\circ}$. On $21^{\text {st }}$ day of incubation, all eggs under study were examined and chicks were investigated for teratogenicity. The results showed marked decrease in hatchability, livability and chick size in all treated subgroups. Also there was a significant increase in dead and resorped chicks percents in all dilutions and periods. The teratological studies revealed a high percentage of skeletal malformations in all treatments especially in inoculation group which show incomplete ossification of frontal and carpus bones, beside absence of patella, curled caudal and pygostyle vertebrae. Concerning visceral abnormalities, the organs size was reduced especially liver with absence of nasal septum and conchae in addition to absence of palatine shelf.
\end{abstract}




\section{INTRODUCTION}

Diseases and infections have always been a major concern to the poultry industry, especially in the hatchery. Fortunately, microbial contamination can be prevented and controlled by using proper management and disinfections. Most of disinfectants are toxic not only for microbial parasites but also for host cells as well. Therefore, they may be used to reduce the microbial population in the inanimate enviroment but they can usually applied only topically not systemically, to humans (Bertram, 1989).

Biocid-30 is one of Iodophore disinfectants that used in cleaning and disinfection of all types of livestock, poultry, processing equipment and surgical instruments. It is used in a dilution of 1:400 for sanitary footbaths on farms and hatcheries and in a dilution of 1:600 for hatcheries and disinfection of fertile eggs before hatching (Pfizer Company, 1997).

Christensen and Ort (1991) found that supplementing 35 or 350 ppm iodine to the basal diet of large white turkey breeder hens resulted in toxic effects on hatchability, depressed egg weights, egg production and eggshell water vapor conductance. Embryonic mortality data indicated that toxic effects of iodine on embryos occur principally during the $1^{\text {st }}$ week of incubation and immediately prior to and during pipping.

On the same line, when iodide administered to poultry in the diet at a dose level of $300 \mathrm{ppm}$, it produces weakness, anorexia, muscular defects, diarrhea and tendency to peck at toes and wing tips. Post mortem picture showed muscular atrophy, degeneration of the liver and kidney with extensive oedema (Katz, 1962).

Further more, Perdomo et. al., (1966) found that when White Leghorn hens were fed on diets containing iodide 312- 5000 ppm for 28 days in a practical laying diet with egg production and hatchability determination. Egg production ceased within the first week in hens fed 
the highest level and production was reduced at lower levels. Fertility of eggs produced was not affected but early embryonic death, reduced hatchability and delayed hatching were resulted.

On the same context, Arrington et. al., (1967) were fed iodides to sexually mature White Leghorn pullets and hens. Dietary intake was in concentration of $625,1250,1875,2500$ and 5000 ppm for 6 weeks. The results were decreasing egg production with increase level of iodine until it becomes ceased with 5000 ppm concentration. The egg fertility was not affected but high embryonic death, low hatchability and delayed hatching were observed.

When 50-hatched eggs were immersed in iodophor compound ( $4 \mathrm{ml} /$ liter of water), absence of coccygeal and pygostyle bones were the malformations appeared (Alkelch, 1985).

Concerning phosphoric acid, and other salts as monosodium phosphate and tetra sodium pyrophosphate were found to produce teratogenic effects when injected during the period of organogenesis in chicken embryos. Several different types of anomalies were observed, mostly structural (Verrett, 1980).

In addition, acidification is associated with increased mortality, reduced growth and bone abnormalities in birds where dietary sulfuric acid levels of 0.122 and $0.56 \mathrm{~mol} \mathrm{H}^{+}$per $\mathrm{kg}$ feed reduce growth and bone mineralization (tibia weight, ash, calcium, phosphorus and plasma concentration of vitamin $\mathrm{D}_{3}$ ) in chicks (Capdevielle, 1998).

On the other side, NTP (National Toxicology Program, 1998) reported that sulfuric acid was not teratogenic in mice and rabbits, but was slightly embryotoxic in rabbits (a minor, rare skeletal variation) where the animals were exposed to 5 and $20 \mathrm{mg} / \mathrm{m} 3$ for 7-hours/ day through out the pregnancy. Previously, Hoffman and Campbell, (1977) were reported that application of sulfuric acid aerosol for chicken eggs result in only a slight decrease in embryonic weight and serum LDH activity with no other apparent effects. 
The aim of the present study is to investigate the toxic and teratogenic effect of Biocid-30 on hatchability and chick embryo and to detect the results if this disinfectant misused in hatcheries by higher concentration than already used in field.

\section{MATERIALS AND METHODS}

Two hundred and twenty fertile eggs from Balady hens (obtained from Poultry Farm of Agriculture college, Tanta University, Kafr El Sheikh branch) were maintained at $30 \mathrm{C}^{\circ}-37 \mathrm{C}^{\circ}$ in incubator. Eggs were candled and proved to be fertile. The selected eggs were classified into 2 main groups.

The first main group (100 fertile eggs) subdivided into:

Group (I): (20 fertile eggs) was dipped in Biocid-30 (Iodine, 2.75\%, Phosphoric acid, 9.5\%, Sulphoric acid, 9.3\% and non ionized substances, $24.2 \%$ - Pfizer company for drugs and chemicals, Egypt) diluted to 1:300 for 1 minute.

Group (II): (20 fertile eggs) was dipped in Biocid-30 diluted to 1:300 for 5 minutes.

Group(III): (20 fertile eggs) was dipped in Biocid-30 diluted to 1:400 for 1 minute.

Group IV (20 fertile eggs) was dipped in Biocid-30 diluted to 1:400 for 5 minutes.

Group (V): (20 fertile eggs) was dipped in distilled water as a control group.

The second main group (120 fertile eggs) subdivided into:

Group (A): (50 fertile eggs) air sac inoculated with Biocid-30 (1:300).

Group (B): (50 fertile eggs) air sac inoculated with Biocid-30 (1:400).

Group (C): (20 fertile eggs) air sac inoculated with $1 \mathrm{ml}$ saline sol. as a control. 
The tested compound was inoculated (1 ml/ $50 \mathrm{gm} \mathrm{egg} \mathrm{weight)}$ using sterile technique into the air sac in the first day of incubation and then the hole in the shell was sealed with paraffin (melting point 56$\left.57 \mathrm{C}^{\circ}\right)$.

On the 21day of incubation, the chicks were removed from incubator and adopted for morphological examination (hatchability $\%$, live and dead $\%$, body weight and body length from the tip of the spine to the top of the skull as described by Alkelch, 1992 in addition to every remarkable abnormalities and character of feather. The chicks were then examined for teratogenicity (Hayes, 1986).

The statistical analysis of the data was carried out according to statistical analysis system (SAS, 1987).

\section{RESULTS}

Morphological examination showed reduction of feathering of hatched chicks as well as delayed hatching time where some eggs were hatched after 1-2 days of normal hatching time especially in inoculated groups.

Table $(1,2)$ shows a significant difference $(p<0.05)$ in size of chicks of treated groups (I, II, III, IV, A, B) as compared with control groups $(\mathrm{V}, \mathrm{C}$ ) where the body weight was $40 \pm 1.34$ in group I (eggs dipped in Biocid-30, 1/300 for 1 minute), 37 \pm 1.12 in group II (eggs dipped in Biocid-30, 1/300 for 5 minutes), 43.5 \pm 1.22 in group III (eggs dipped in Biocid-30, 1/400 for 1 minute) and 41 $\pm 1.24 \mathrm{gm}$ in group IV (eggs dipped in Biocid-30, 1/400 for 5 minutes) but was $49.5 \pm 1.3 \mathrm{gm}$ in control group $(\mathrm{V})$. 
In inoculation treatment, group A (eggs inoculated with Biocid-30, $1 / 300$ ), the weight was $28 \pm 1.03$ and $30 \pm 1.14 \mathrm{gm}$ in group $B$ (eggs inoculated with Biocid-30, 1/400) but was $49 \pm 1.23 \mathrm{gm}$ in control group (C).

Also the body length was $7.5 \pm 0.24 \mathrm{~cm}$ in group I and 7.1 \pm 0.11 , $8.1 \pm 0.14$ and $7.6 \pm 0.13 \mathrm{~cm}$ in groups II.III and VI respectively but was $8.9 \pm 0.21 \mathrm{~cm}$ in control group $(\mathrm{V})$.

In inoculation groups, the length was $5.9 \pm 0.13$ and $6.3 \pm 0.21 \mathrm{~cm}$ in group $\mathrm{A}$ and $\mathrm{B}$ respectively whether the length was $8.7 \pm 0.14 \mathrm{~cm}$ in control group (C).

More over, table $(3,4)$ show significant decrease in hatchability percent $(70,55,80,75)$ in dipping groups (I, II, III, IV respectively) in comparison with control group (V) in which the hatchability percent was 95. Also the inoculation groups (A, B) show more significant decrease in hatchability percent $(12,18$ respectively) when compared with the control one $(90 \%)$. Further more, there were decreased live percent and increased dead percent in all treated groups when compared with control groups. The resorption percent was very high and appears in dipping and more seriously in inoculation groups.

Concerning the teratogenic effect of Biocid-30, there was high percent of skeletal abnormalities in all treatments including incomplete ossification of frontal and carpus bones, absence of patella and curled pygostyl and caudal vertebrae. The abnormalities were higher in percentage and more obvious in inoculation groups. The visceral abnormalities appeared in all treated groups especially inoculation groups in the form of reduced organs weight especially liver, absence of nasal septum and conchae, in addition to absence of palatine shelf. 
Toxicological Effect Of The Disinfectant Biocid-30 On ...

Table (1): Reduction of chick weight and length of Biocid-30 dipped eggs.

\begin{tabular}{|c|c||c||}
\hline Group & Body weight (gm) & Body length $(\mathbf{c m})$ \\
\hline \hline Group I & $40 \pm 1.34^{\mathrm{b}}$ & $7.7 \pm 0.24^{\mathrm{b}}$ \\
\hline Group II & $37 \pm 1.12^{\mathrm{a}}$ & $7.1 \pm 0.11^{\mathrm{a}}$ \\
\hline Group III & $43.5 \pm 1.22^{\mathrm{d}}$ & $8.3 \pm 0.14^{\mathrm{c}}$ \\
\hline Group VI & $41 \pm 1.24^{\mathrm{c}}$ & $7.6 \pm 0.13^{\mathrm{b}}$ \\
\hline Group V & $49.5 \pm 1.3^{\mathrm{e}}$ & $8.9 \pm 0.21^{\mathrm{d}}$ \\
\hline
\end{tabular}

N.B.

- Values in the same column with different superscripts vary significantly at $\mathrm{P}<0.05$.

- Group V = Control group in dipping treatment .

Table (2): Reduction of chick weight and length of Biocid-30 inoculated eggs.

\begin{tabular}{|c||c||c|}
\hline Group & Body weight $(\mathbf{g m})$ & Body length $(\mathbf{c m})$ \\
\hline \hline Group A & $28 \pm 1.03^{\mathrm{a}}$ & $5.8 \pm 0.13^{\mathrm{a}}$ \\
\hline Group B & $30 \pm 1.14^{\mathrm{b}}$ & $6.5 \pm 0.21^{\mathrm{b}}$ \\
\hline Group C & $49 \pm 1.23^{\mathrm{c}}$ & $8.9 \pm 0.14^{\mathrm{c}}$ \\
\hline
\end{tabular}

N.B.

- Values in the same column with different superscripts vary significantly at $\mathrm{P}<0.05$.

- Group C = Control group in inoculation treatment.

Table(3):Percent of different abnormalities obtained in dipping treatment compared with non treated group.

\begin{tabular}{|c||c||c|c|c|}
\hline Group & Hatchability\% & Live\% & Dead\% & Resorption\% \\
\hline \hline Group I & 70 & 85.71 & 14.29 & 25 \\
\hline Group II & 55 & 72.73 & 27.23 & 20 \\
\hline Group III & 80 & 87.5 & 12.5 & 15 \\
\hline Group VI & 75 & 82 & 18 & 10 \\
\hline Group V & 95 & 89.47 & 10.53 & 5 \\
\hline
\end{tabular}

N.B.

- Group V = Control group in dipping treatment

$\overline{\text { Kafr El-Sheikh Vet. Med. J. Vol. } 3 \text { No. } 1 \text { (2005) }}$ 
Ghada M.Gomaa, Yosef T.A., et.al.

Table (4): Percent of different abnormalities obtained in inoculation treatment compared with non treated group.

\begin{tabular}{|c||c||c||c|c|}
\hline Group & Hatchability\% & Live\% & Dead\% & Resorption\% \\
\hline \hline Group A & 12 & 16.66 & 83.44 & 60 \\
\hline \multirow{2}{*}{ Group B } & 18 & 22.22 & 77.88 & 76 \\
\hline Group C & 90 & 88.89 & 11.11 & 5 \\
\hline
\end{tabular}

- Group $\mathrm{C}=$ Control group in inoculation treatment

Table (5): Teratogenic effect of Biocid-30 on chicks (dipping groups).

\begin{tabular}{|l||c|c|c|c||c|c|c|c||}
\hline \multirow{2}{*}{} & \multicolumn{4}{|c||}{ Skeletal abnormalities \% } & \multicolumn{3}{c||}{ Visceral abnormalities \% } \\
\cline { 2 - 9 } & $\begin{array}{c}\text { Incomplete } \\
\text { ossification } \\
\text { I.O) of } \\
\text { frontal bone }\end{array}$ & $\begin{array}{c}\text { I.O of } \\
\text { carpus } \\
\text { bone }\end{array}$ & $\begin{array}{c}\text { Absence } \\
\text { of patella }\end{array}$ & $\begin{array}{c}\text { Curled } \\
\text { caudal } \\
\text { vertebrae }\end{array}$ & $\begin{array}{c}\text { Malformed } \\
\text { cleft palate }\end{array}$ & $\begin{array}{c}\text { Absence } \\
\text { of nasal } \\
\text { septum }\end{array}$ & $\begin{array}{c}\text { Absence } \\
\text { of nasal } \\
\text { conchae }\end{array}$ & $\begin{array}{c}\text { Absence } \\
\text { of } \\
\text { palatine } \\
\text { shelf }\end{array}$ \\
\hline \hline Group I & 76.42 & 65 & 85 & 90 & 56 & 40 & 30 & 32 \\
\cline { 2 - 9 } Group II & 81.50 & 70.2 & 88.4 & 94.6 & 66.3 & 48.6 & 30 & 34.7 \\
\cline { 2 - 9 } GroupIII & 72 & 61.3 & 79.7 & 85 & 52.8 & 36.5 & 45 & 28 \\
\cline { 2 - 9 } & 74.66 & 63 & 82 & 91.5 & 61.8 & 36 & 47.8 & 28.7 \\
\hline GroupIV & zero & zero & zero & zero & zero & zero & zero & zero \\
\hline Group V & & & & & & & & \\
\hline
\end{tabular}

Table (6): Teratogenic effect of Biocid-30 on chicks (inoculation groups).

\begin{tabular}{|c|c|c|c|c|c|c|c|c|}
\hline \multirow[b]{2}{*}{ Group } & \multicolumn{4}{|c|}{ Skeletal abnormalities \% } & \multicolumn{4}{|c|}{ Visceral abnormalities \% } \\
\hline & \begin{tabular}{|c} 
Incomplete \\
ossification \\
(I.O) of frontal \\
bone
\end{tabular} & $\begin{array}{l}\text { I.O of } \\
\text { carpus } \\
\text { bone }\end{array}$ & $\begin{array}{c}\text { Absence of } \\
\text { patella }\end{array}$ & $\begin{array}{c}\text { Curled } \\
\text { caudal } \\
\text { vertebrae }\end{array}$ & $\begin{array}{l}\text { Malformed } \\
\text { cleft palate }\end{array}$ & $\begin{array}{l}\text { Absence } \\
\text { of nasal } \\
\text { septum }\end{array}$ & $\begin{array}{l}\text { Absence } \\
\text { of nasal } \\
\text { conchae }\end{array}$ & $\begin{array}{c}\begin{array}{c}\text { Absence } \\
\text { of } \\
\text { palatine } \\
\text { shelf }\end{array} \\
\end{array}$ \\
\hline Group A & 90.5 & 92 & 92.5 & 91 & 79.6 & 68 & 56 & 48 \\
\hline Group B & 88.2 & 90 & 91 & 89 & 78 & 64.5 & 41 & 46.4 \\
\hline Group C & 4.4 & 3 & 4.6 & 2.3 & 1.6 & 1.1 & 1.6 & 1 \\
\hline
\end{tabular}

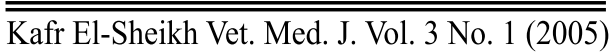




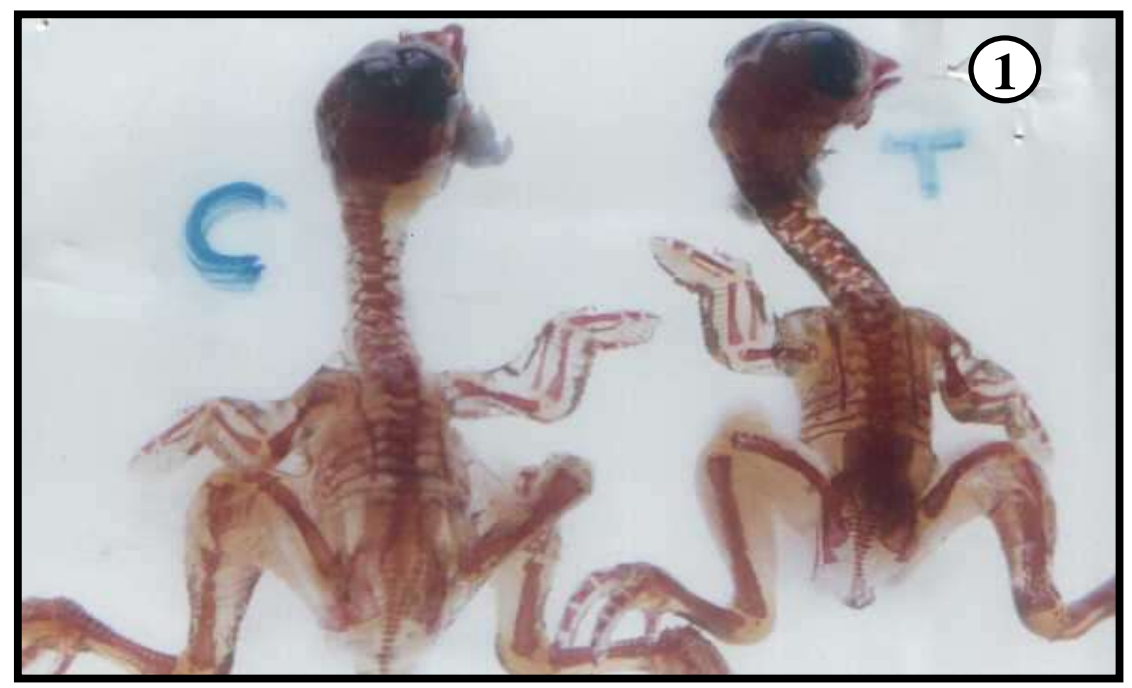

Fig (1): Chicken embryo of Biocid-30 (1/300) dipped fertile egg for 5 minutes (right) showing: incomplete ossification of frontal bone and beakshaped pyramidal face, compared with the control chicken embryo (left).

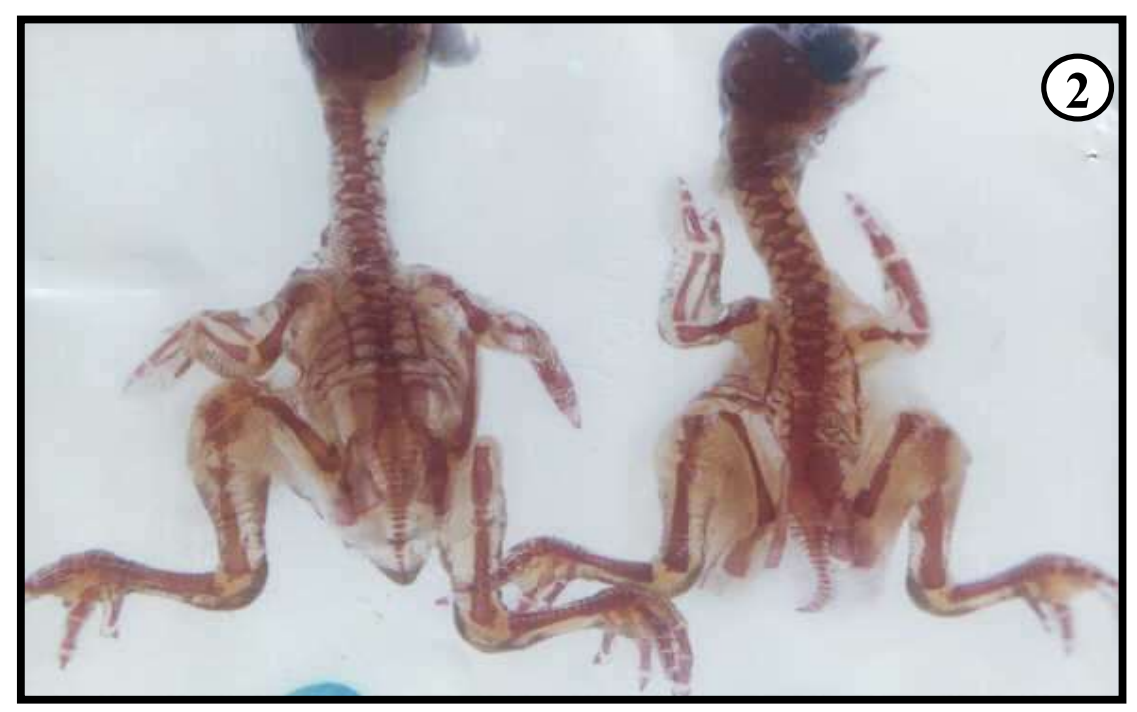

Fig (2): Chicken embryo of Biocid-30 (1/300) inoculated fertile egg (right) showing: absence of patella and curled pygostyle and caudal vertebrae, compared with the control chicken embryo (left). 


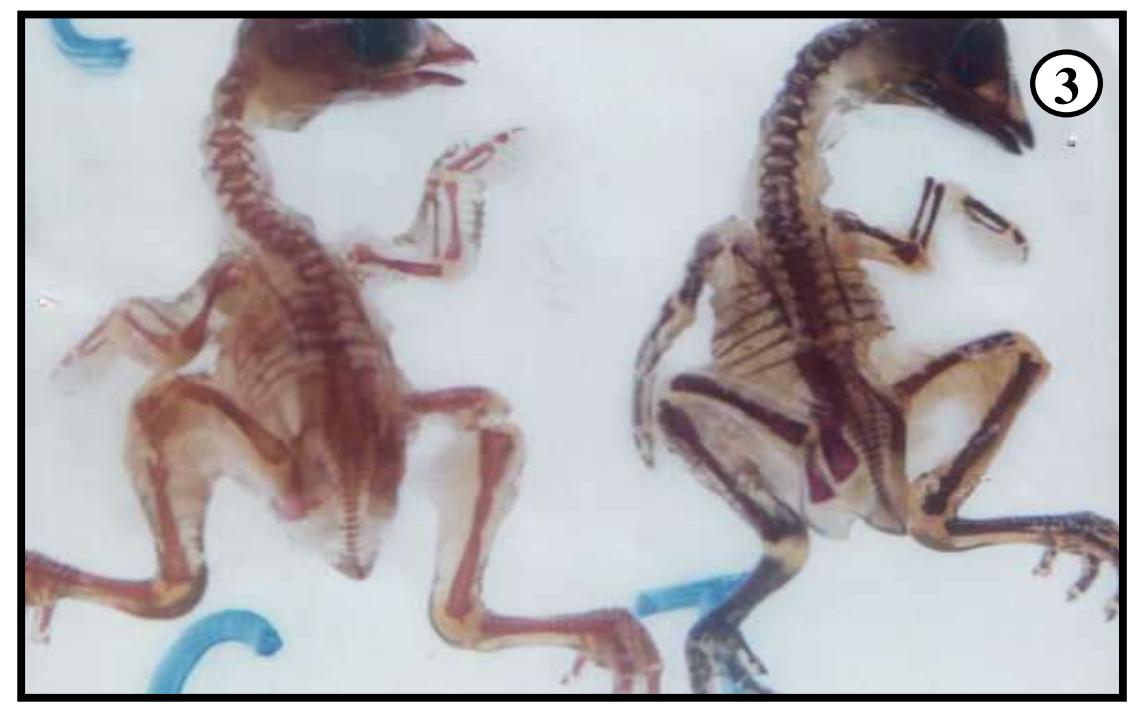

Fig (3): Chicken embryo of Biocid-30 (1/400) dipped fertile egg for 5 minutes (right) showing: incomplete ossification of carpus bones, compared with the control chicken embryo (left).

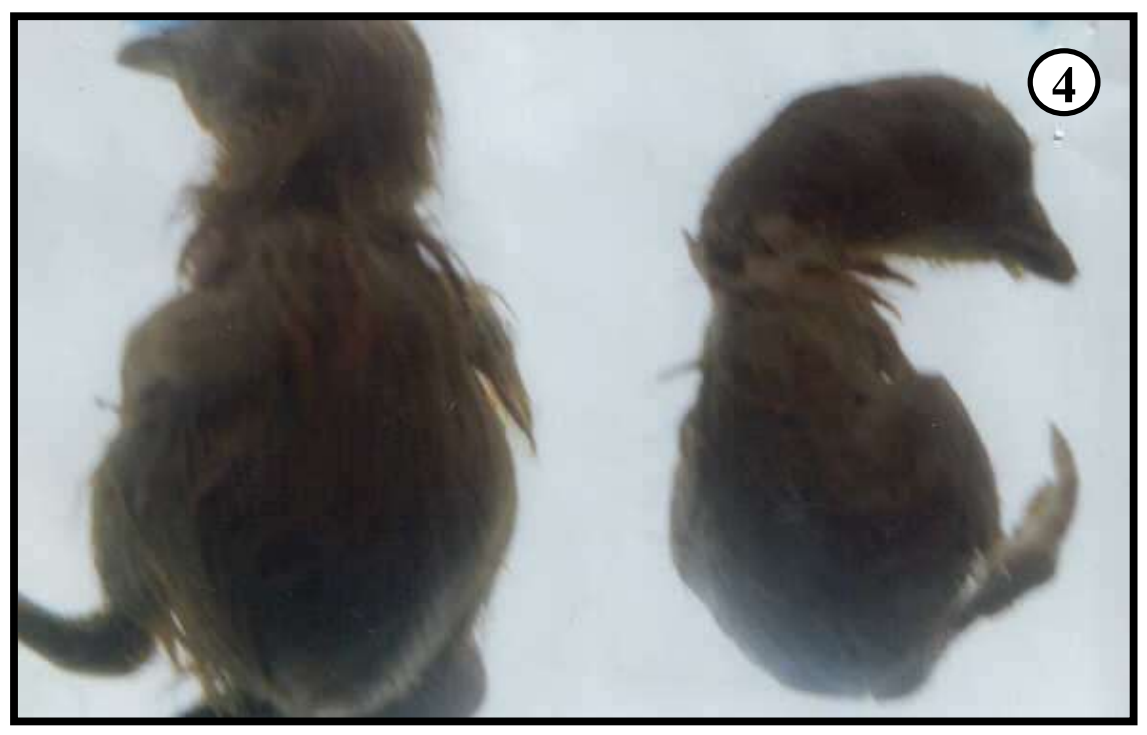

$\overline{\overline{\text { Kafr El-Sheikh Vet. Med. J. Vol. } 3 \text { No. } 1 \text { (2005) }}}$ 
Fig (4): Chicken embryo of Biocid-30 (1/400) inoculated fertile egg (right) showing: remarkable decrease in size, compared with the control chicken embryo (left).

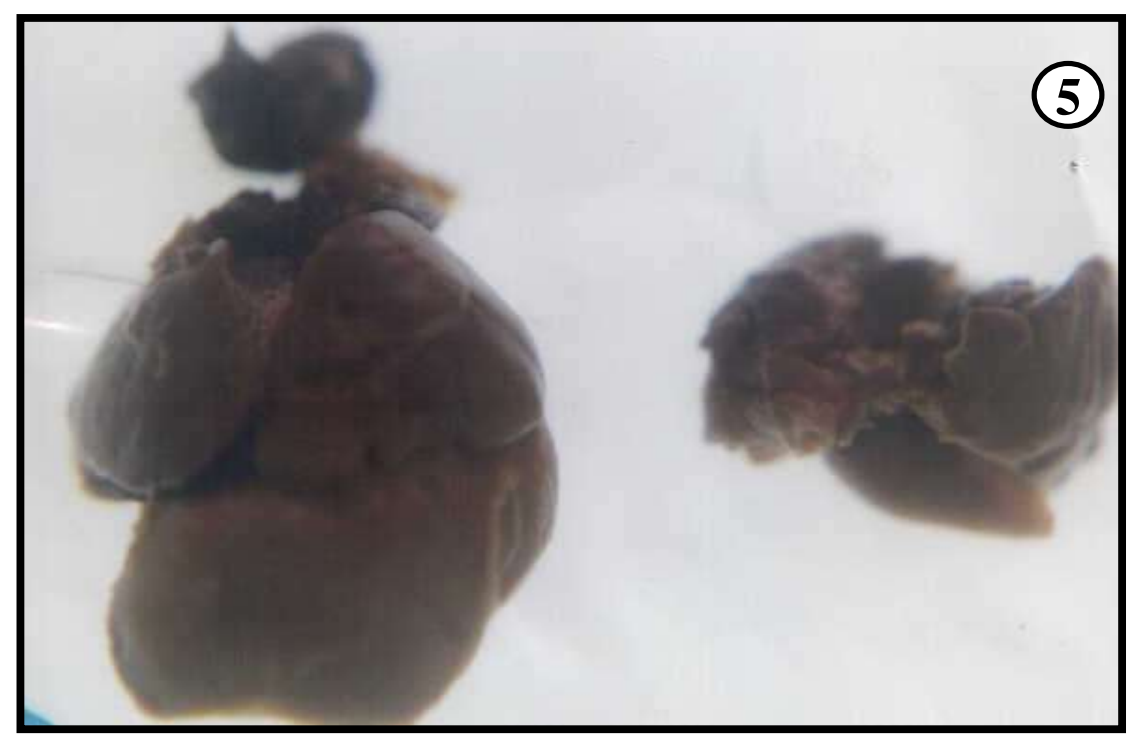

Fig (5): liver of chicken embryo of Biocid-30 (1/300) dipped fertile egg for 1 minute (right) showing: remarkable decrease in size, compared with the control chicken embryo liver (left).

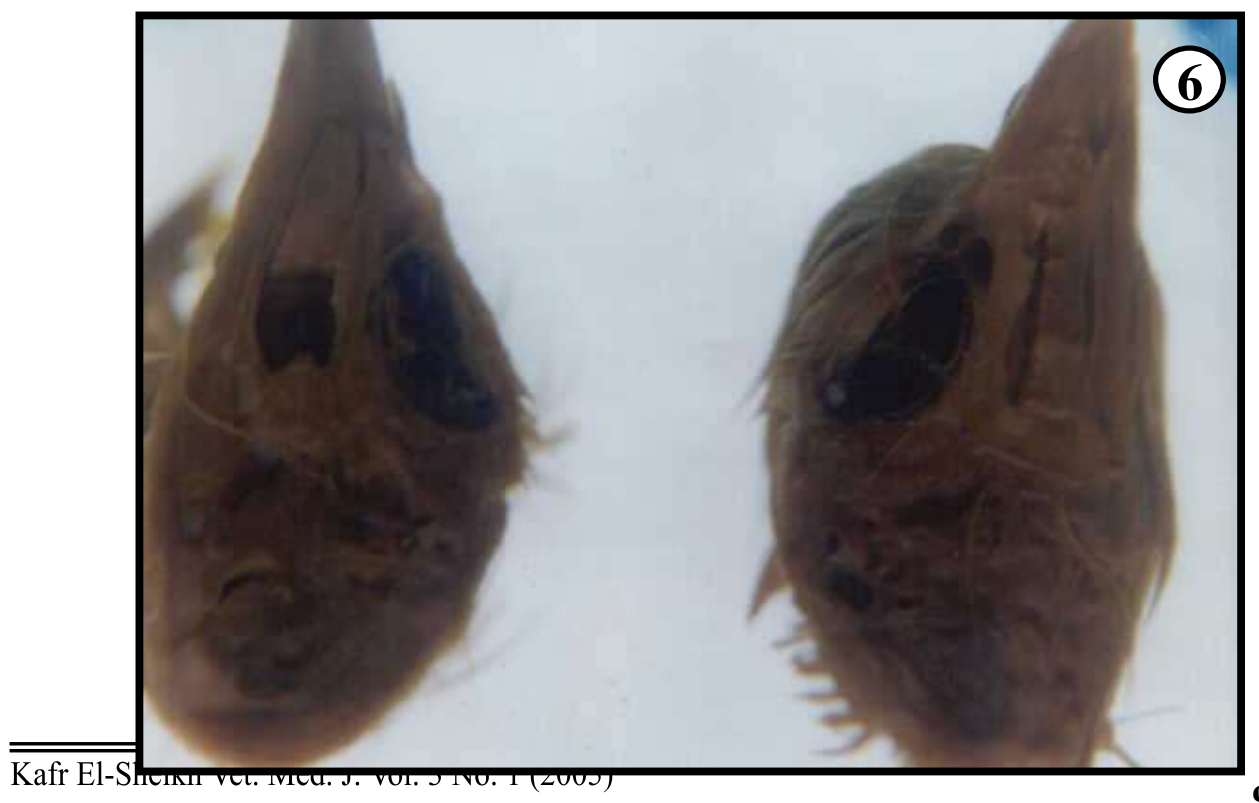


Fig (6): Head section of chicken embryo of Biocid-30 (1/400) dipped fertile egg for I minute (right) showing: malformed cleft palate, compared with the control chicken embryo head section (left).

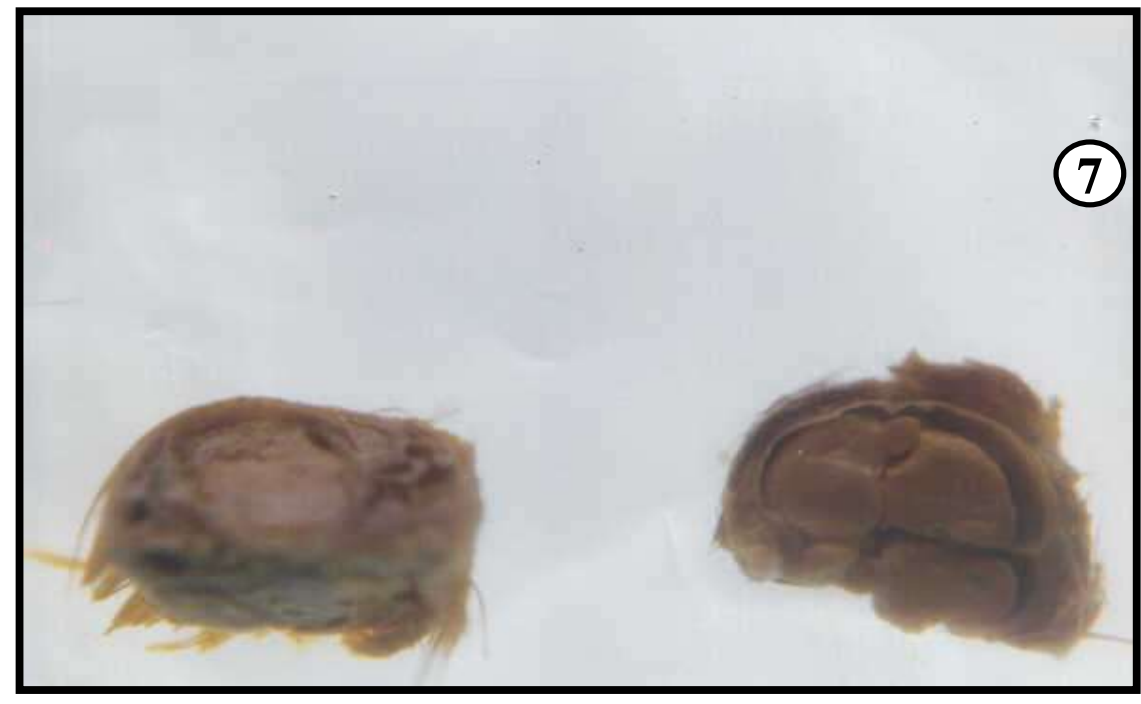

Fig (7): Head section of chicken embryo of Biocid-30 (1/300) inoculated fertile egg (left) showing: absence of nasal septum, conchae and palatine shelf, compared with the control chicken embryo head section (right).

\section{DISCUSSION}

Teratogenicity in chick embryos was classified into two groups according to its harmful effect. Some of them may cause macroscopical abnormalities and others cause microscopical malformations (Kalow and Marton, 1961 and Mosceoni et. al., 1977). Both types of teratogenic effects were observed in the present study. The most critical period for teratogenesis in our work was the first week of incubation (the period of differentiation into muscle, cartilage, bone and connective tissue), Hamburger and Hamilton, (1951)

The delayed egg hatching may be due to high iodine level where iodine injection prior to incubation result in a significantly greater 
thyroid gland weight on day 18 of incubation and a delay in hatching (Guo et. al., 1998).

It is the fact that, the pores in the eggshell are essential to the development of embryos in hatching eggs as they allow the exchange of respiratory gasses and water vapor conductance (Burton and Tullet, 1983). Since, the cuticle, which is glycoprotein in nature, covers the pores, it is considered as physical barrier to liquid water and foreign particles penetration (Broad and Fuller, 1994). It is generally agreed that, the only route available for antiseptics to penetrate the intact shell of the avian egg is via pores (Board and Board, 1967). Also careful studies by Favier et.al.,(2001) indicated that detergents could have a deleterious effect on the cuticle thus enhancing bacterial and foreign materials transmission across the shell. The eggshell is more sensitive to acidic condition. Regarding Biocid-30 components, sulfuric and phosphoric acids constitute the main components and increasing the acidity on the eggshell.

The embryotoxic effect of the iodine compounds may be referred to mutagenic effect of iodine antiseptics (Wlodkowski, et. al., 1975) and the bad effect of iodine on the viability of chicken embryos, Youseif et. al., (2000). It is fact that embryonic body weight and crown- rump length faithfully echo the embryonic development coupled with the concept that many chemicals may destroy cellular active DNA and so reduced biosynthesis of essential components, like protein and energy sources (ATP and NAD/NADH) (Haschek and Rousseaux, 1993). Given the previous tapestry, we are led to believe that the highly significant decrease in both embryonic weights and lengths, in addition to decreased organs size seen with the Biocid-30 treatments may referred to the effect of iodine which capable of modifying the DNA of the living cells (Wlodkowski et. al., 1975).

Concerning skeletal malformations appeared in this research, they may be due to high acidity caused by phosphoric and sulfuric acids in Biocid-30 where acidification is associated with increased mortality, 
reduced growth and bone abnormalities in birds. These effects noticed by Capdevielle et. al., (1998) in chicks on the high acid (sulfuric, 0.122 and $0.56 \mathrm{~mol} \mathrm{H}+$ per $\mathrm{kg}$ feed) diet where there were marked decrease in bone growth, mineralization (tibia weight, ash, calcium, phosphorus and plasma concentration of vit. $\mathrm{D}_{3}$ )

\section{REFERENCES}

- Alklech, A.M.M. (1985): Toxicological studies on some disinfectants.Ph. D of medical Jurisprudence and Toxicology. Faculty of Vet. Med., Zagazig University.

- Alkelch, A.M.M (1992): Teratogenic effect of the insecticide Methidathion- 40 on chick embryo and its effect in combination with its antidotal treatment. Zagazig Vet. J., 20(3): 332-340.

- Arington,L.; Santa Cruz, R.; Harms, R. and Wilson, H. (1967): Effect of excess dietary iodine upon pullets and laying hens.J. Nutrition, 92: 325-330.

- Bertram, G.K. (1989): Basic and clinical pharmacology, fifth edition.

- Board, P.A. and Board, R.G. (1967): A method of studying bacteril penetration of the shell of the hen's egg. Lab. Pract., 16(29): 271$272 ; 482$.

- Board, R.G. and Fuller, R. (1994): Microbiology of the Avian Egg. London, Glasgow, New york, Tokyo, Melbourne and Madras. Champman and Hall. Pp.: 1-58.

- Burton, F. and Tullett, S.G. (1983): A comparasion of the effects of egg shell porosity on the respiration and growth of domestic fowl, duck and turkey embryos. Comp. Biochem. Physiol., 75A: 167-174.

- Capdevielle, M.C.; Hart, L.E.; Goff, J. and Scanes, C.G. (1998): Aluminum and acid effects on calcium and phosphorus metabolism in young growing chickens (Gallus gallus domesticus) and mallard 
ducks (Anas platyrhynchos). Joint Program in Toxicology, Rutgers, New jersey 08854, USA.

- Christensen, V.L. and Ort, J.F. (1991): Iodine toxicity in large white turkey breeder hens. Department of Poultry Science, North Carolina University, Raleigh 27695-7608.

- Favier, G.L.; Escudero, M.E. and Guzman, A.M. (2001): Effect of chlorine, sodium chloride, trisodium phosphate and ultraviolet on the reduction of Yersinia enterocolitica and mesophilic aerobic bacteria from egg shell surface. J. Food Prot., 64(10): 1621-1623.

- Guo, Z.; Narbaitz, R. and Fryer, J.N. (1998): Effects of excess iodine in chick embryo thyroid follicles: initial inhibition and subsequent hypertrophy. Department of anatomy, University of Ottawa, Faculty of Medicine, Ontario, Canada.

- Hamburger, V. and Hamilton, H.L. (1951): A series of normal stages in the development of the chick embryo. J. Morph. 88: 49-89. Page No. 586

- Haschek, W.M. and Rousseaux, C.G. (1993): Fundementals of Toxicologic Pathology. London, Academic Press. pp.:68-140, 515541.

- Hayes, A.W. (1986): Principles and Methods of Toxicology. New York, Raven Press. pp. : 141-184.

- Hoffman, D.J. and Campbell, K.I. (1977): Embryotoxicity of irradiated and non irradiated catalytic converter treated automotive exhaust. J. Toxicol. Environ. Health, 1977 Nov;3 (4): 705-12.

- Kalow, W. and Marton, A. (1961): Second generation toxicity of malation in rats. Nature 192: 4640465.

- Katz, R. (1962): Iodine toxicity in poultry. J. Vet. Res. Broad of Canada, 31 (4): 480-485.

- Mosceoni, A.D.; Engee, J.L. and Casida, J.E. (1977): Kynurnine formatidase inhibition as a possible mechanism for 
certainteratogenic effects of organophosphorus and methyl carbamate insecticides in chick embryos. Biochem. Pharmacol. 26, 2251-2258.

- Perdomo, J.; Harms, R. and Arrington, L. (1966): Effect of dietry iodine upon egg production, fertility and hatchability. Proceeding of the Society for Experimental Biology and Medicine, 122: 758-760.

- Pfizer Company (1997): Direction for use of Biocid-30. Produced by Evans Vanodine international Plc.

- SAS, (1987): Statistical Analysis System, User's Guide. SAS Institute Inc. Cary, N.C., USA.

- U. S. NTP (National Toxicology Program) (1998): Evaluation of risk to human reproduction. Research Triangle Park, North Carolina, (NTP.TR 342).

- Verrett, M. (1980): Toxicity and teratogenicity of food additive chemicals in the developing chicken embryo. Toxicol. Appl. Pharmacol., 56,265-273.

- Wlodkowski, T.J.; Speck, W.T. and Rosenkranz, H.S. (1975): The temporary nature of the inhibitory action of excess iodide on organic iodine synthesis in the normal thyroid. J. Biol. Chem., 175: 504-513.

- Youseif, H.; Ali, M. and Hassanein, Z. (2000): The efficiency of some disinfectants against chicken embryo bacterial infections. J. Egypt. Vet. Med. Ass., 60(1); 89-96.

$$
\text { التأثير السمى لمطهر البيوسيد - } 30 \text { على أجنة الطيور }
$$

غادة محمود جمعة ، طارق أحمد علد الهادى ، أبو النصر أبو زهرة

قسم الفارماكولوجيا والطب الثرعى والسموم - كلية الطب البيطرى بكفر الثيخ / جامعة طنطا

أجريت هذه الدراسة لمعرفة الناثير السمى و التشوهات الجنينية التى قد يسببها مطهر البيوسيد30 إذا ما نم استخدامه بتركيز اكبر من المتعارف علية فى المفرخات. 
استخدم عدد 220 بيضة مخصبة و مقسمة الى مجموعتين رئيسيتين، الأولى (100 بيضة) قسمت الى خمسة مجاميع فرعية منساوية، غمرت مجموعتين منها بمطهر البيوسيد-30 نركيزة

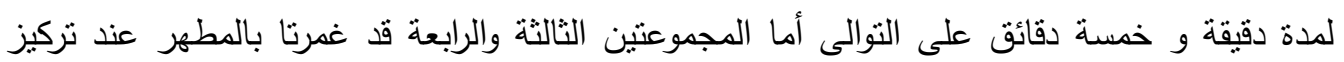

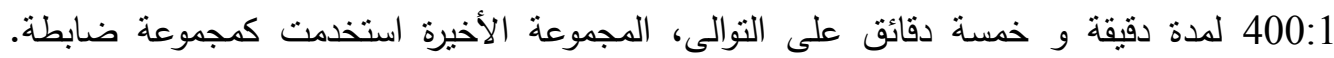
بالنسبة للمجوعة الرئيسية الثانية والتى تحتوى على 120 بيضة مخصبة قسمت إلى ثلاثلاث مجاميع

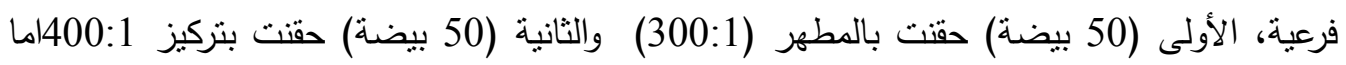

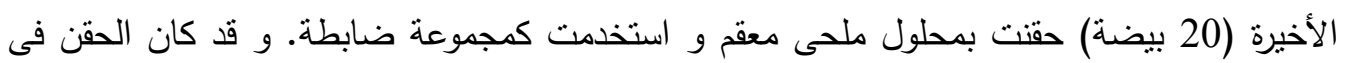

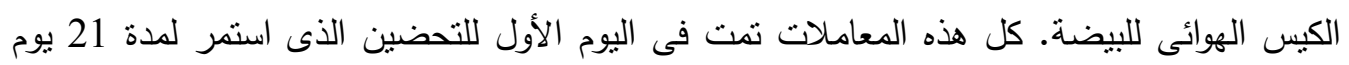

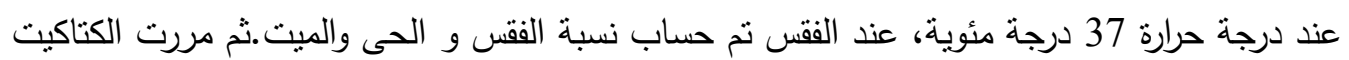
لفحص التشوهات العظمية والحشوية.

و قد وجد انخفاض كبير فى نسبة الفقس ووزن الكتكوت و ارتفاع نسبة الفاقد و الميت من

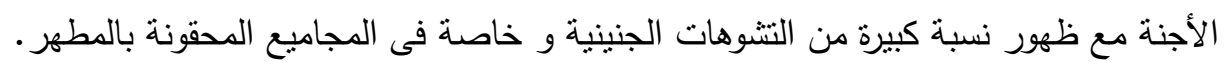

